\title{
DAHBOARD EKSEKUTIF SEBAGAI MEDIA KOORDINASI DAN MONITORING KEGIATAN UNTUK PENINGKAT KINERJA APARATUR PEMERINTAH
}

\author{
Mohammad Reza Maulana*, Anas Syaifudin, Hari Agung Budijanto, Eko Budi Susanto \\ STMIK Widya Pratama Pekalongan \\ Jl Patriot No 25 Pekalongan Phone 427816, \\ Korespondensi : reza.stmikwp@gmail.com
}

\begin{abstract}
Pekalongan City Government continues to strive to improve good governance in maximizing the use of Information Technology, this is evidenced by the participation of the Pekalongan City Government in the Movement Towards 100 Smart City programs. One effort that can be made to optimize the use of information technology is the executive dashboard for monitoring $R T / R W$ activities. In 2019, Pekalongan City has $340 \mathrm{RW}$ and 1660 RT. The existence of this executive dashboard application can optimize the role of $R T$ and $R W$ and all information at the lower level can be obtained immediately, such as information on population data, submission of grants and assistance, and others. The information in the monitoring dashboard is the realtime data that currently exists. This research will make a dashboard monitoring $R T$ / $R W$ activities with a prototype model approach. The prototype model and Joint Application Development (JAD) are the most widely used models in creating executive dashboards. The research steps started from data collection, data analysis, application design, application development and testing. From the data collected, a functional and non-functional requirements analysis process was carried out. After that the application design process is carried out and continued with the design implementation in the application development process. Then from the results of the Alpha Test and Beta Test, the application can work according to functional and non-functional needs. In the future, this application prototype can be developed in conjunction with the One Data application in Dinas Komunikasi dan Informatikan (Diskominfo) Pekalongan City.
\end{abstract}

Keywords: Executive dashboard, smart city, prototype.

\section{PENDAHULUAN}

Kota Pekalongan merupakan salah satu dari 100 kota yang ada di Indonesia yang turut dalam program Gerakan Menuju 100 Smart City. Hal ini menjadikan bukti bahwa Kota Pekalongan berupaya dalam meningkatkan tata kelola pemerintahan Good Governance dan berinovasi dalam mengoptimalkan penggunaan Teknologi Informatika (Pekalongan, 2018). Sinergi pada semua tingkatan di lingkungan Pemerintah Kota Pekalongan akan membantu terwujudnya Smart City yang baik, terutama peranan aparatur pemerintah yang paling bawah, yaitu Ketua RT dan RW.

Pada tahun 2019, ada 1.660 RT di Kota Pekalongan dan dari tahun ke tahun jumlahnya cenderung bertambah. Banyaknya RT di Kota Pekalongan merupakan potensi luar biasa jika mampu mengoptimalkan peranan RT dan RW, namun juga menjadi tantangan bagi Pemerintah Kota Pekalongan dalam mengkoordinasi dan memantau RT/RW yang ada.

Untuk melakukan koordinasi dan memonitoring kegiatan-kegiatan yang ada di Kota Pekalongan dapat menggunakan sebuah aplikasi dashboard eksekutif. Dashboard eksekutif RT/RW merupakan solusi untuk menangani kesulitan Pemerintah Kota Pekalongan dalam memonitoring kegiatankegiatan di masyarkat dengan cepat. Dengan dashboard eksekutif RT/RW ini, maka dapat didorong peningkatan peranan aparatur RT dan RW untuk bekerjasama dengan aparatur Pemerintah Kota Pekalongan di lingkungan OPD dalam menyelesaikan masalah yang terjadi. 
Dashboard eksekutif RT/RW merupakan sebuah tampilan informasi (user interface) berbentuk grafis yang memberikan visualisasi performance dengan menggunakan indikatorindikator tertentu sebagai dasar tampilan informasi. Sebagai contoh kasus saat ini, jika diterapkan untuk penanganan wabah Covid-19, maka indikator dalam dashboard tersebut, berupa data Orang Dalam Pemantauan (ODP), Pasien Dalam Pengawasan (PDP), suspect, Orang Tanpa Gejala (OTG), pendatang dari daerah pandemik atau data lainnya yang diperlukan. Digital dashboard RT/RW ini menjadi pusat kontrol dari segalanya dan memiliki kemampuan untuk memberikan deteksi peringatan dini (alarm/early warning system) jika ada informasi yang bersifat sangat penting atau bahaya (kenaikan/penurunan sesuatu), baik itu dalam bentuk suara, teks, warna atau bahkan kombinasi ketiganya. Keberadaan dashboard RT/RW ini akan sangat membantu Pemerintah Kota Pekalongan dalam mengontrol dan menangani suatu masalah besar di Kota Pekalongan.

Pada penelitian sebelumnya yang dilakukan oleh Dewi dkk, (2015) mengembangkan Dashboard Executive Information System Pada Desa Banjar, Kabupaten Buleleng Berbasis Web di Provinsi Bali. Hasil dari penelitian tersebut didapatkan bahwa aplikasi dapat mempermudah pencarian informasi-informasi yang ada pada Kabupaten Banjar sehingga dapat meminimalkan waktu yang diperlukan, mempermudah user dalam melihat data-data penduduk secara visual. Pada penelitian lain yang dilakukan oleh Yudiantara dkk, (2019) membangun Dashboard Executive Information System dengan Pendekatan Sistem Terdistribusi untuk Pemantauan Penyaluran Kredit KUR Mikro Bank X. Hasil dari penelitian tersebut, yaitu sistem dapat melakukan sinkronisasi data nasabah antar kantor unit, adanya grafik untuk menyajikan perbandingan jumlah nasabah, penerapan teknologi web service yang mendukung pertukaran data secara real-time, serta sinkronisasi dua arah antar kantor unit yaitu insert, update, delete dan read dari database.

Oleh karena itu, dengan terwujudnya Dashboard RT/RW ini akan membantu pemerintah dalam mendapatkan data secara real-time dan dapat digunakan untuk memantau kondisi yang ada. Dashboard RT/RW ini memiliki banyak fungsi, jika nanti wabah virus Covid-19 sudah tuntas tertangani, maka dashboard ini dapat difungsikan untuk: (1) memantau jika ada wabah demam berdarah; (2) memantau jika terjadi bencana banjir; (3) memantau penyebaran dana hibah di wilayah Kota Pekalongan; (4) memantau potensi wisata/kuliner/industri kreatif yang muncul; dan masih banyak manfaat lainnya.

\section{TINJAUAN PUSTAKA}

\subsection{Information Dashboard Executive}

Information dashboard executive merupakan visualisasi data dalam bentuk dashboard yang digunakan untuk menggambarkan informasi di setiap proses bisnis yang bertujuan untuk memudahkan para eksekutif dalam menentukan kebijakan dengan cepat (Sofyan \& Nugroho, 2016).

Dashboard executive adalah aplikasi yang dapat menampilkan ringkasan data secara realtime dan melaporkan berbagai informasi dari berbagai sumber data dalam lingkup tertentu perusahaan atau lembaga yang berguna dalam mendukung dan menentukan arah kebijakan dan keputusan (Kurniawan \& Ashari, 2015).

Dari beberapa literatur yang ada dapat disimpulkan bahwa dashboard eksekutif merupakan sistem informasi yang dapat memberikan informasi dalam bentuk visual yang dapat digunakan para eksekutif dalam menentukan keputusan atau kebijakan.

Dashboard memiliki tampilan panel secara visual dari informasi-informasi penting yang dibutuhkan, terkonsolidasi dan tersusun dalam sebuah tampilan layar di mana informasi tersebut dapat dicerna secara sekilas dan mudah untuk diekplorasi lebih dalam (Turban, 2011). Fitur yang paling khas dari dashboard adalah tiga lapisan atas informasi, yaitu monitoring, analisis dan manajemen. Fungsi dashboard bagi manajemen adalah menampilkan data operasional yang rinci yang mengidentifikasi tindakan yang harus dilakukan manajemen untuk menyelesaikan masalah (Turban, 2011). 
Menurut Henderi (2012) dalam pengembangan dashboard digital dapat menggunakan beberapa pendekatan, yaitu:

a) Joint Application Development (JAD)

b) Prototyping

c) Services Oriented Architecture (SOA)

Metodologi Prototyping dan JAD paling banyak digunakan dalam pengembangan dashboard eksekutif.

\subsection{Smart City}

Konsep Kota Cerdas (Smart City) awalnya diciptakan oleh perusahaan IBM. Sebelumnya berbagai nama sempat dibahas para ahli dunia dengan nama Digital City atau Kota Cerdas (Smart City) . Intinya Kota Cerdas (Smart City) ini menggunakan teknologi informasi untuk menjalankan roda kehidupan kita yang lebih efisien. Versi IBM, Kota Cerdas (Smart City) adalah sebuah kota yang instrumennya saling berhubungan dan berfungsi cerdas. Kota Cerdas (Smart City) adalah sebuah konsep kota cerdas/pintar yang membantu masyarakat yang berada di dalamnya dengan mengelola sumber daya yang ada dengan efisien dan memberikan informasi yang tepat kepada masyarakat/ lembaga dalam melakukan kegiatannya atau pun mengantisipasi kejadian yang tak terduga sebelumnya.

Kota Cerdas (Smart City) cenderung mengintegrasikan informasi di dalam kehidupan masyarakat kota. Definisi lainnya, Kota Cerdas (Smart City) didefinisikan juga sebagai kota yang mampu menggunakan SDM, modal sosial, dan infrastruktur telekomunikasi modern untuk mewujudkan pertumbuhan ekonomi berkelanjutan dan kualitas kehidupan yang tinggi, dengan manajemen sumber daya yang bijaksana melalui pemerintahan berbasis partisipasi masyarakat (PUPR, 2020).

Konsep Kota Cerdas (Smart City) pada umumnya meliputi:

a) Sebuah kota berkinerja baik dengan berpandangan ke dalam ekonomi, penduduk, pemerintahan, mobilitas, dan lingkungan hidup.

b) Sebuah kota yang mengontrol dan mengintegrasi semua infrastruktur.

c) Kota Cerdas (Smart City) dapat menghubungkan infrastuktur fisik, infrastruktur IT, infrastruktur sosial, dan infrastruktur bisnis untuk meningkatkan kecerdasan kota.

d) Kota Cerdas (Smart City) membuat kota lebih efisien dan layak huni.

e) Penggunaan smart computing untuk membuat Kota Cerdas (Smart City) dan fasilitasnya saling berhubungan dan efisien.

\section{METODE PENELITIAN}

Metode penelitian yang digunakan adalah metode campuran, yaitu menggunakan metode kuantitatif dan kualitatif dalam mendapatkan data. Data yang didapatkan nantinya digunakan untuk menganalisa permasalahan, kebutuhan pembuatan aplikasi dan hasil dari penelitian.

Pertama, yang dilakukan adalah pengumpulan data dengan beberapa metode yang digunakan, yaitu teknik studi lapangan, studi literatur, wawancara, dan kuesioner. Studi di lapangan dilakukan melalui pengamatan secara langsung terhadap kegiatan-kegiatan yang terkait dengan objek penelitian. Selain itu teori dan hasil kajian dari jurnal juga digunakan untuk mendukung data yang ada melalui studi literatur. Selanjutnya teknik wawancara dan kuesioner digunakan untuk mengumpulkan data dari narasumber secara langsung yang berhubungan dengan objek yang diteliti.

Setelah data-data awal berhasil dikumpulkan, tahap selanjutnya adalah melakukan identifikasi permasalahan beserta kebutuhan-kebutuhan yang harus dipenuhi, baik kebutuhan fungsional maupun kebutuhan non fungsional dari sistem yang akan dibangun dan merangkumnya ke dalam sebuah solusi. Selanjutnya, dari solusi yang dihasilkan akan dilanjutkan dengan membuat desain konseptual dan detail desain dari sistem yang akan dibangun.

Tahap selanjutnya, setelah desain telah selesai dibuat, maka pembuatan prototipe aplikasi dilakukan. Setelah prototipe selesai dibuat, tahap terakhir adalah menguji prototipe tersebut dengan model functional testing dan closed beta testing.

\section{HASIL DAN PEMBAHASAN \\ 4.1. Pengumpulan Data Awal}

Pengumpulan data ini dilakukan agar mengetahui kebutuhan fungsional dan non 
fungsional sistem yang akan dibangun. Beberapa teknik yang dilakukan dalam pengumpulan data antara lain:

Wawancara secara tatap muka langsung dilakukan dengan Ketua RW 08 di Kelurahan Gamer, Kecamatan Pekalongan Timur, Kota Pekalongan. Selain wawancara langsung secara tatap muka, juga dilakukan pengumpulan data melalui media elektronik di beberapa wilayah seperti: Wilayah RW. 12 Kelurahan Krapyak, Kecamatan Pekalongan Utara, Wilayah RW. 08 Kelurahan Bendan Kergon, Kecamatan Pekalongan Barat.

Dari hasil wawancara yang dilakukan di beberapa wilayah yang telah disebutkan, didapatkan hasil bahwa:

a) Ketua RW/RT mengalami kesulitan mengatasi wabah penyakit, bencana (banjir, dll) yang terjadi, kesulitan untuk melaporkan perkembangan wabah penyakit/bencana yang terjadi, kesulitan untuk melaporkan kebutuhan urgent masyarakat terdampak wabah penyakit/bencana, kesulitan untuk meneruskan aspirasi/harapan masyarakat terdampak wabah penyakit/bencana di wilayahnya dengan segera.

b) Ketika mendapatkan hibah dari pemerintah atau ingin mendapatkan hibah, Ketua RW/RT mengalami kesulitan dalam mengusulkan permohonan hibah kepada pemerintah, kemudian pada saat mendapatkan hibah Ketua RW/RT harus melaporkan pemakaian dan realita pada saat mendapatkan hibah kepada pemerintah.

c) Ketua RW/RT mengalami kesulitan untuk mengembangkan potensi daerah (wisata/kuliner/industri kreatif) yang ada di wilayahnya, kesulitan untuk mengusulkan atau mendapatkan program pembinaan potensi daerah di wilayahnya agar dapat berkembang dengan baik, kesulitan untuk meneruskan aspirasi/harapan masyarakat yang terlibat dalam pengembangan potensi yang ada.

Berdasarkan hasil wawancara yang telah dilakukan, maka diperlukan solusi untuk mengatasi permasalahan tersebut, salah satu solusi yang diusulkan adalah adanya jembatan aspirasi/pengaduan secara langsung dan realtime kepada pemerintah untuk melaporkan setiap kegiatan, wabah penyakit/bencana, adanya potensi daerah yang muncul di setiap wilayah.

Salah satu solusi yang dapat diterapkan adalah dibangunnya aplikasi dashboard eksekutif RT/RW, melalui aplikasi ini pemerintah dapat menentukan kebijakan strategis terkait permasalah yang ada seperti: adanya wabah/pandemi suatu penyakit, bencana, dana hibah/bantuan sosial di RT/sekolah, potensi wisata/kuliner/industri kreatif yang muncul.

Ketua RW/RT sebagai wakil dari masyarakat disetiap daerah dapat secara langung menyampaikan data atau informasi dan perkembangan daerahnya kepada masyarakat. Data dan informasi tersebut dapat dijadikan sebagai bahan pertimbangan bagi pemerintah untuk menentukan langkah-langkah kebijakan yang diambil oleh pemerintah.

\subsection{Analisa Kebutuhan Sistem}

Data yang didapatkan kemudian diolah dan dilakukan analisa untuk menentukan kebutuhan fungsional dan non-fungsional sistem. Aplikasi Dashboard Eksekutif RT/RW yang diusulkan memiliki kebutuhan fungsional sistem antara lain:

a) Aplikasi dapat melaporkan data terbaru jumlah penduduk yang ada di wilayah $\mathrm{RT} / \mathrm{RW}$.

b) Aplikasi dapat melaporkan adanya wabah penyakit/bencana yang terjadi di lingkungan RT/RW, kebutuhan urgent masyarakat terdampak wabah penyakit/bencana.

c) Aplikasi dapat melaporkan permohonan/ penyaluran hibah/bantuan/potensi daerah di lingkungan RT/RW.

d) Aplikasi dapat memberikan data dan informasi kepada pemerintah terkait wabah penyakit/bencana, permohanan/penyaluran hibah, potensi daerah di setiap RT/RW, dan aspirasi dari masyarakat.

e) Aplikasi dapat memberikan data dan informasi kepada pemerintah terkait wabah penyakit/bencana, permohanan/penyaluran hibah, potensi daerah di setiap RT/RW, dan aspirasi dari masyarakat.

f) Data dan informasi yang disampaikan dapat diketahui secara real-time, dapat diakses 
melalui berbagai macam platform, baik melalui smartphone/laptop atau komputer.

g) Statistik data atau informasi yang tampilkan dapat disajikan dalam bentuk grafik/gambar.

Sedangkan kebutuhan non fungsional sistem aplikasi dashboard eksekutif RT/RW yang diusulkan antara lain:

a) Tampilan aplikasi bersifat responsif, dapat menyesuikan perangkat yang digunakan

b) Tampilan/interface yang sederhana dan dapat dipahami oleh pengguna

c) Memiliki tingkat keamanan yang baik untuk melindungi data dan informasi yang telah tersimpan.

\subsection{Desain}

Setelah dilakukan analisa kebutuhan fungsional dan non-fungsional sistem berdasarkan data dari pegumpulan data, langkah berikutnya adalah membuat desain sistem yang diusulkan.

\subsubsection{Desain Alur Sistem}

Ketua RT/RW melaporkan data dan informasi yang diperoleh melalui aplikasi dashboard eksekutif RT/RW. Pemerintah melalui aplikasi dashboard eksekutif RT/RW dapat melihat data dan informasi yang dilaporkan dalam bentuk statistik grafik. Data dan informasi tersebut dijadikan dalam menentukan arah kebijakan publik.



Gambar 1 Alur Sistem yang Diusulkan

\subsubsection{Desain Database}

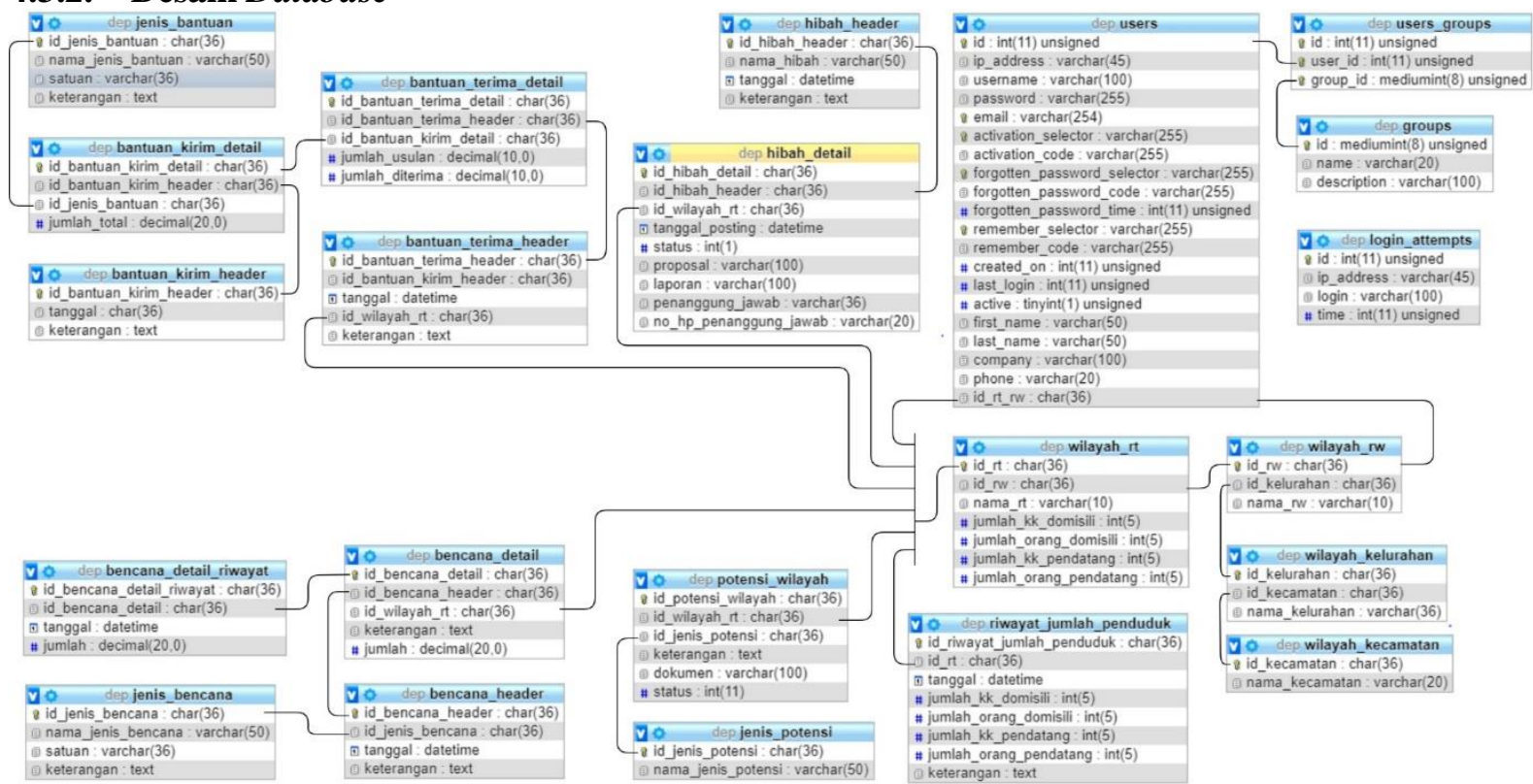

Gambar 2 Desain Database Dari Aplikasi yang Akan Dibangun 


\subsection{Pembangunan Sistem}

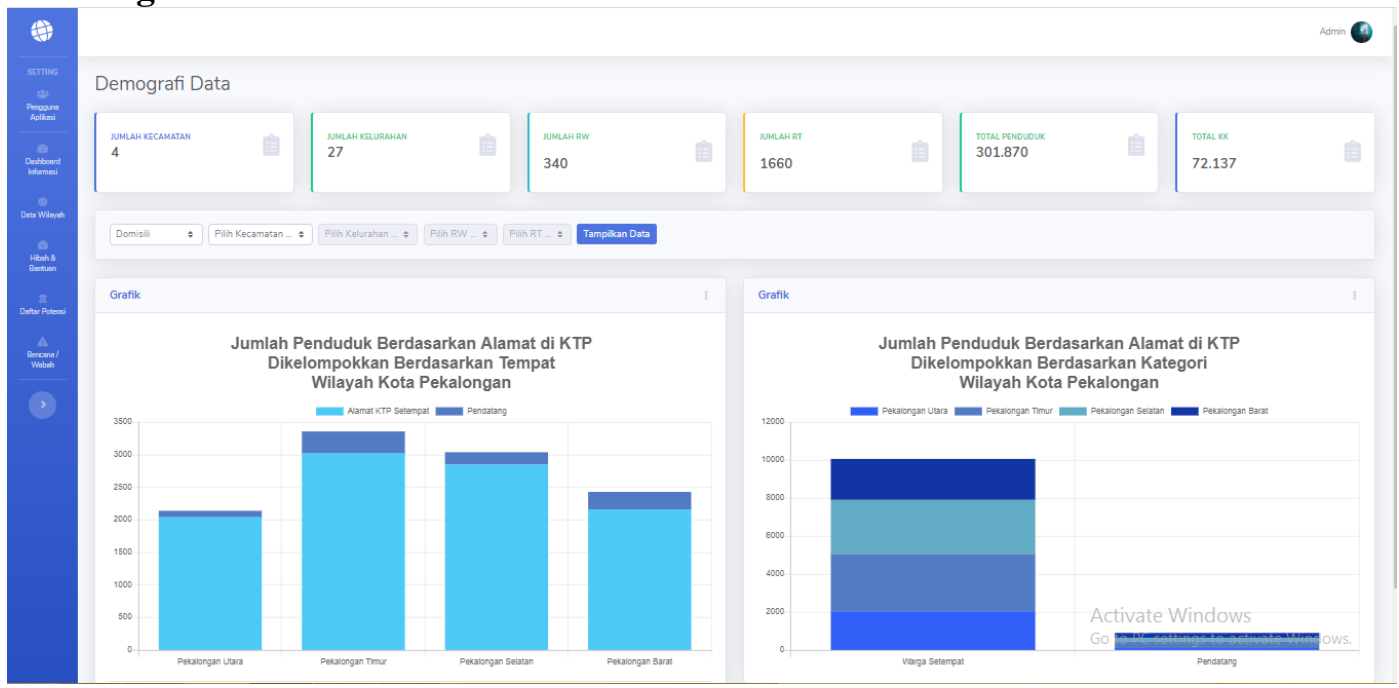

Gambar 3 Dashboard Demografi Penduduk

Gambar 3 merupakan tampilan dashboard yang berisi informasi dalam bentuk grafik. Data di grafik muncul sesuai dengan parameter yang dipilih, sebagai contoh menampilkan demografi penduduk berdasarkan domisili, usia dan jenis kelamin.
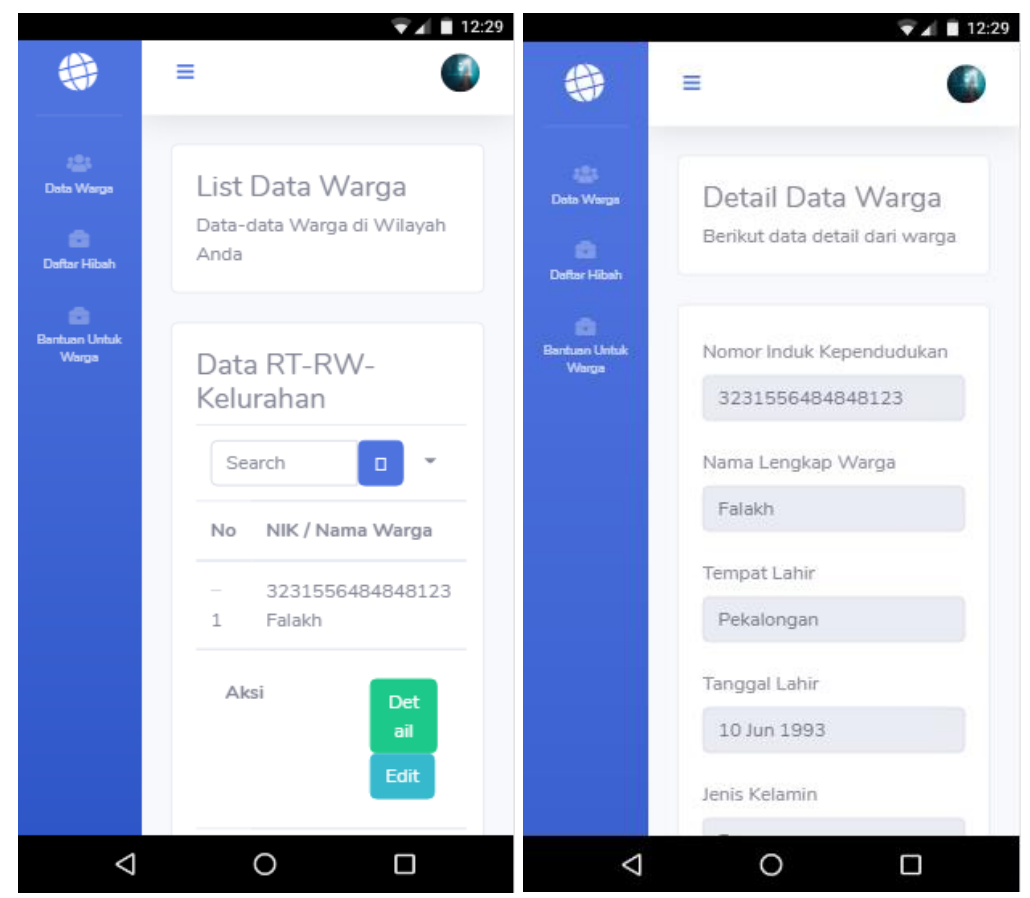

Gambar 4 Tampilan Menu Data Warga dari sisi RT/RW

Gambar 4 merupakan tampilan dari sisi RT/RW di mana dapat melakukan manajemen data penduduk di wilayahnya.

\subsection{Pengujian}

Setelah dilakukan implementasi sistem, tahap selanjutnya adalah melakukan pengujan sistem. Pengujian sistem dilakukan dengan cara menguji kesesuaian dari kebutuhan fungsional 
dan non-fungsional sistem. Terdapat 2 jenis pengujian yang dilakukan, yaitu Alpha Testing dan close beta testing.

Pengujian alpha (alpha testing) merupakan pengujian dari sisi fungsional yang diuji dari sisi pengembang, yang berarti apakah sistem dapat berjalan dengan semestinya. Dari beberapa pengujian ditemukan beberapa bug dan sudah dapat teratasi. Selain itu fitur-fitur yang ada sudah berjalan sesuai dengan fungsinya.

Pengujian close beta merupakan pengujian yang dilakukan oleh orang lain diluar pengembang aplikasi. Dari beberapa pengguna yang diundang untuk melakukan pengujian, terdapat 65 orang yang melakukan pengujian. Mekanisme pengujian close beta dengan cara peserta diberi akses masuk aplikasi kemudian menjawab beberapa pertanyaan di dalam kuesioner yang tersedia. Dari hasil pengujian ini didapatkan hasil lebih dari $80 \%$ penguji memastikan aplikasi dapat berfungsi dengan baik, sesuai dengan kebutuhan fungsional dan non-fungsional.

\section{KESIMPULAN}

\subsection{Simpulan}

Dari pembahasan yang telah dilakukan, maka dapat disimpulkan beberapa hal, yaitu: terwujudnya prototipe aplikasi dashboard monitoring kegiatan RT/RW. Kemudian dari hasil pengujian alpha (alpha testing) didapatkan hasil bahwa aplikasi dashboard monitoring kegiatan bisa berjalan dan berfungsi dengan baik. Selanjutnya, untuk hasil pengujian close beta (close beta testing) didapatkan hasil bahwa kebutuhan fungsional dan nonfungsional sistem sudah dapat berfungsi dengan baik.

Aplikasi yang dibangun masih sangat perlu untuk dikembangkan dan diuji lagi, mengingat aplikasi yang dibangun masih dalam bentuk prototipe. Beberapa saran pengembangan ke depannya dari prototipe yang ada adalah:

a) Walaupun aplikasi web yang dibangun sudah menggunakan pendekatan mobile friendly, ke depannya perlu dibuatkan dengan model native agar dapat performa dapat lebih bagus. b) Dinas Komunikasi dan Informatika (Diskominfo) Kota Pekalongan memiliki aplikasi One Data di mana setiap data dari OPD dimasukkan di aplikasi ini. Aplikasi dashboard monitoring dapat dikembangkan dan disinkronisasikan dengan aplikasi One Data dari Diskominfo.

\subsection{Tindak Lanjut}

Penelitian ini dapat ditindaklanjuti dengan beberapa kegiatan-kegiatan yang dapat menunjang penerapan aplikasi dashboard monitoring kegiatan ini. Beberapa kegiatan tersebut antara lain:

a) Berdasarkan informasi dari Ana Mahyurotun, S.Si selaku Kepala Seksi Pengelolaan Statistik Daerah Bidang Pengelolaan Infrastruktur Informatika dan Statistik Daerah, saat ini Diskominfo sedang mengembangkan aplikasi One Data yang dapat menampilkan data-data dalam bentuk grafik dan diagram agar data dapat tervisualisasi dengan lebih baik dan mudah dibaca. Pengembangan ini dapat disinkronisasikan dengan dashboard monitoring kegiatan RT/RW yang nantinya juga dapat dikembangkan lebih lanjut lagi sesuai dengan kebutuhan visualisasi data.

b) Jika dashboard monitoring kegiatan RT/RW ini diselaraskan dengan aplikasi One Data dari Diskominfo, maka perlu kajian tambahan dari fitur-fitur yang ada agar dapat berjalan secara beriringan yang saling mendukung satu sama lain.

c) Jika nantinya aplikasi dashboard monitoring ini akan digunakan, maka perlu diadakannya sosialisasi kepada ketua RT/RW seluruh wilayah Kota Pekalongan agar dapat menggunakan aplikasi dashboard monitoring ini. Mekanisme sosialisasi dapat mengundang satu/dua kelurahan di setiap sesinya.

\section{DAFTAR PUSTAKA}

Dewi, Z. R., Ahmadi, C., \& Suardika, I. G. (2015). Dashboard Executive Information System Pada Banjar Berbasis Web. Jurnal Online Sistem Informasi (JOSINFO) Vol. 1, No. 1, Mei 2015, 1-9. 
Henderi, Rahayu, S., \& Prasetyo, B. M. (2012).

Dashboard Information System

berbasis Key Performance Indicator.

Seminar Nasional Informatika 2012

(semnasIF 2012) (hal. d82-d87).

Yogyakarta: UPN "Veteran"

Yogyakarta.

Kurniawan, K., \& Ashari, A. (2015). Service

Orchestration using Enterprise Service

Bus for Real-time Government

Executive Dashboard System. 2015

International Conference on Data and

Software Engineering IEEE, 207-212.

Pekalongan, K. (2018, Agustus). Kota

Pekalongan Optimalkan Program

Pekalongan Smart City. Diambil

kembali dari pekalongankota.go.id:

https://pekalongankota.go.id/berita/kota

--pekalongan-optimalkan--program-

pekalongan-smart-city.html

PUPR, K. (2020). Konsep Kota Baru. Diambil

kembali dari Perencanaan Kawasan

Pemukiman Kota Baru:

http://sim.ciptakarya.pu.go.id/kotabaru/ site/konsepkotabaru/21

Sofyan, H., \& Nugroho, S. P. (2016).

Pengembangan Academic Information

Dashboard Executive (A-Index) dengan

Pentaho Data Integration dan

QLIKVIEW (Studi Kasus : Prodi

Teknik Informatika UPN "Veteran"

Yogyakarta). TELEMATIKA, Vol. 13,

No. 01, Januari, 2016, 17-22.

Turban, E. (2011). Decision Support and

Business Intelligence System, 9th

edition. New Jersey: Pearson Education Inc.

Yudiantara, P. O., Sukarsa, I. M., \& Sutramiani, N. P. (2019). Dashboard Executive Information System dengan Pendekatan Sistem Terdistribusi untuk Pemantauan Penyaluran Kredit KUR Mikro Bank X. MERPATI VOL. 7, NO. 1 APRIL 2019, 67-76. 